\title{
DISPOSISI MATEMATIS ANAK USIA DINI (STUDI KASUS DI KELOMPOK A PAUD PERMATA HATI AISYIYAH TASIKMALAYA)
}

\author{
Milah Nurkamilah $^{1}$, Mirawati $^{2}$, Cucu Arumsari ${ }^{3}$ \\ Universitas Muhammadiyah Tasikmalaya \\ Email : milah.nurkamilah@umtas.ac.id,mirapaud@umtas.ac.id, \\ cucu.arumsari@umtas.ac.id
}

\begin{abstract}
ABSTRAK
Artikel ini merupakan hasil penelitian yang bertujuan untuk mendeskripsikan 1) pembelajaran matematika yang dapat mengembangkan disposisi matematis anak di kelompok A PAUD Permata Hati Aisyiyah, dan 2) mendeskripsikan kecenderungan disposisi matematis anak usia 3-5 tahun di kelompok A PAUD Permata Hati Aisyiyah. Jenis penelitian yang digunakan adalah penelitian kualitatif dengan metode studi kasus. Subjek penelitian yaitu siswa kelompok A PAUD Permata Hati Aisyiyah Kota Tasikmalaya. Hasil penelitian menunjukkan 1) disposisi matematis anak memiliki potensi kemunculan lebih banyak pada aktifitas pembelajaran yang menggunakan media nyata dan berbasis aktifitas untuk anak, dan 2) anak usia 3-4 tahun menununjukkan kecenderungan disposisi matematis berkembang pada aspek percaya diri terhadap kemampuan matematika dan rasa ingin tahu terhadap matematika. Sedangkan pada usia 4-5 tahun, cenderung menunjukkan kemunculan disposisi matematis yang dominan pada kepercayaan diri, rasa ingin tahu, daya cipta, serta sedikit frekuensi kemunculan pada ketekunan, fleksibilitas dan apresiasi matematis.
\end{abstract}

Kata Kunci: disposisi matematis, matematika anak, PAUD.

\begin{abstract}
This article is the result of research that aims to describe 1) mathematics learning that can develop mathematical dispositions of children in group A PAUD Permata Hati Aisyiyah, and 2) describe the tendency of mathematical dispositions of children aged 3-5 years in group A PAUD Permata Hati Aisyiyah. Qualitative research with a case study method used in this research. The research subjects were group A students of Permata Hati Aisyiyah PAUD, Tasikmalaya City. The results showed that 1) the mathematical disposition of children has more potential for emergence in learning activities that use real object and activity-based for children, and 2) 3-4 year olds show a tendency for mathematical dispositions to develop on aspects of self-confidence in mathematical abilities and curiousity about mathematics. Whereas at the age of 4-5 years, it tends to show the emergence of dominant mathematical dispositions on self-confidence, curiosity, inventiveness, and a slight frequency in perseverance, flexibility and mathematical appreciation.
\end{abstract}

Keywords: mathematical disposition, childr mathematics, PAUD.

\section{PENDAHULUAN}

Permasalahan

pembelajaran matematika, masih menjadi isu utama dalam pendidikan di Indonesia mulai dari tingkat dasar sampai tingkat menengah, bahkan perguruan tinggi. Hal ini diindikasikan dengan masih rendahnya prestasi belajar dalam mata pelajaran matematika di setiap jenjang. Disamping itu, matematika seringkali menjadi mata pelajaran yang sulit, tidak 
menyenangkan dan cenderung identik dengan hitungan atau hapalan rumus. Padahal, mata pelajaran matematika diberikan salah satunya bertujuan untuk menumbuhkan kesadaran bahwa matematika dekat dengan kehidupan sehari-hari, berharga untuk menunjang kemajuan zaman dan menumbuhkan kecenderungan positif siswa untuk tertarik terhadap matematika (Nurkamilah, 2018: 78).

Anak secara alami memiliki ketertarikan terhadap matematika. Vygotsky menyatakan anak secara alamiah memiliki kemampuan dalam mempelajari matematika dan mengembangkan ketertarikannya terhadap matematika (Saraman \& Clements, 2009: 3). Middleton \& Spanias (Clements \& Sarama, 2009: 211) menyatakan bahwa anak usia dini secara intuisi memiliki perasaan yang positif terhadap matematika dan termotivasi untuk melakukan eksplorasi bilangan dan bentuk. Hal ini perlu disadari oleh orang tua dan guru, sehingga mampu mendukung perkembangan pengetahuan informal dan intuisi matematis anak.

Ketertarikan, intuisi dan kemampuan alami yang dimiliki anak sekiranya perlu mendapat perhatian khusus. Artinya matematika perlu dikenalkan kepada anak semenjak usia dini dengan cara yang tepat sehingga keterampilan matematisnya dapat berkembang secara optimal. Pengetahuan matematika sejak usia dini berpengaruh terhadap kesuksesan belajar dalam matematika untuk jenjang pendidikan selanjutnya, dan memiliki korelasi terhadap prestasi belajar matematika selanjutnya termasuk keterampilan membaca, bahkan berkorelasi terhadap karir seseorang di masa depan (Sarama \& Clements, 2009: 5; Duncan, et al., 2007: 1428; NMP, 2008: 25; Watts, et al., 2014: 5).

The National Association for Education of Young Children (NAEYC) menyatakan pembelajaran matematika dengan kualitas tinggi dapat diperoleh salah satunya apabila guru mengembangkan ketertarikan alami siswa dan disposisi anak untuk memahami dunia fisik dan sosialnya menggunakan matematika (NAEYC, 2002: 3). Hal ini menjadi penekanan bahwa aktivitas matematika di PAUD, selain membekali anak dengan kemampuan pemahaman konsep (bilangan, bentuk, pengukuran dan pola matematis) serta keterampilan matematis lainnya, namun aktivitas yang dibangun untuk menanamkan konsep tersebut perlu dirancang sehingga menstimulasi perkembangan disposisi matematis anak sebagai salah satu kecakapan matematis.

$$
\text { Disposisi matematis yang }
$$
berkembang sejak usia dini menimbulkan sikap dan apresiasi positif terhadap matematika. Pengertian disposisi matematis dinyatakan oleh Kilpatrick, Swafford \& Findel (2001: 116) yaitu merupakan kecenderungan terbiasa melihat matematika mudah dipahami, berguna dan berharga, relevan, menyatu dengan keyakinan dalam ketekunan dan efikasi diri. Katz mendefinisikan disposisi matematis dalam konteks matematika sebagai kecenderungan untuk berperilaku sadar, teratur, dan sukarela yang terlihat pada bagaimana anak 
menyelesaikan masalah mateamtis melalui perilaku percaya diri, tekun, berminat, dan berpikir fleksibel (Mahmudi, 2010: 5).

Hal ini sejalan dengan yang dikemukakan oleh NCTM (1989: 233) bahwa disposisi mengacu kepada sikap, dan kecenderungan untuk berpikir dan bertindak secara positif terhadap matematika, yang ditunjukkan oleh pendekatan yang dilakukan anak terhadap tugas matematika dan kecenderungan untuk merefleksikan pemikiran matematis. Penilaian mengenai disposisi matematis (NCTM, p.233) berarti berupaya untuk menemukan informasi mengenai, (1) Kepercayaan diri dalam menggunakan matematika; (2) Fleksibilitas dalam mengeksplorasi ide-ide matematis; (3) Keinginan dan ketekunan dalam menyelesaikan tugas matematika; (4) Ketertarikan, keingintahuan, dan daya cipta dalam melakukan matematika; (5) Keinginan untuk memantau dan merefleksikan pemikiran dan kinerjanya sendiri; (6) Penghargaan terhadap penggunaan matematika dalam disiplin ilmu lain dan pengalaman sehari-hari; dan (7) Apresiasi terhadap peran matematika dalam budaya serta nilainya sebagai alat dan bahasa.

Disposisi matematis merupakan faktor penting dalam pencapaian prestasi belajar matematika bagi anak. Disposisi mendorong pengaruh positif terhadap kemampuan pemecahan masalah anak, termasuk dalam memecahkan masalah kehidupan sehari-hari (Rahayu \& Kartono, 2014: 1318). Mengembangkan disposisi matematis anak berarti menstimulasi kesadaran anak terhadap kehadiran matematika dalam kehidupan seharihari di sekitar anak, mudah dipahami, menyenangkan, menarik, serta memberikan kesempatan untuk merefleksikan dunianya secara matematis. Anak akan termotivasi untuk aktif terlibat dalam aktivitas pembelajaran matematika.

Namun Hiebert (Sarama \& Clements, 2009: 6) menyatakan terjadi celah pengetahuan matematika anak akibat kurangnya hubungan antara pengetahuan informal atau intuitif anak dengan matematika sekolah. Padahal, pengetahuan matematika anak pada usia dini merupakan pengetahuan informal atau intuitif dari matematika. Banyak anak mengalami pengalaman negatif terhadap matematika di sekolah, cenderung tidak menyukai matematika, berpandangan bahwa matematika sulit, membosankan, tidak relevan dengan kehidupan sehari-hari serta tidak berharga (Graven, M., 2016: 2; Colgan, L., 2014: 1).

Seiring dengan pengalaman dan interaksi anak di sekolah, anak mulai meyakini bahwa hanya beberapa orang yang memiliki kemampuan matematika. Hasil penelitian pada siswa SMP kelas VIII menunjukkan bahwa anak masih memiliki efikasi diri rendah terhadap matematika (Nurkamilah, 2016: 183). Padahal, anak dapat menguasai keterampilan yang dibutuhkan jika diberikan kesempatan (Clements, Endowed, \& Sarama, 2013: 5).

Oleh karena itu, perlu adanya 
studi terhadap aktivitas pembelajaran matematika di pendidikan anak usia dini sebagai langkah awal meletakkan ketertarikan anak terhadap matematika. Termasuk menyelidiki sejauh mana program belajar yang sudah dirancang bagi anak usia dini mampu mengembangkan disposisi matematis anak. Observasi perlu dilakukan untuk mengetahui bagaimana disposisi matematis anak usia dini sudah dikembangkan, serta bagaimana karakteristik program belajar anak usia dini di taman kanak-kanak yang dapat mestimulusi berkembangnya disposisi matematis.

Pola asuh di Pendidikan Anak Usia Dini (PAUD) Permata Hati Aisyiyah Kota Tasikmalaya berdasarkan visinya membentuk anak yang cerdas, terampil, islami, unggul dalam berprestasi dengan salah satu misinya menekankan pada pengembangan potensi dan tumbuh kembang anak berbasis kecerdasan jamak (Multiple Intelegence) berlandaskan Iman dan Taqwa (Imtaq) dan Ilmu Pengetahuan dan Teknologi (IPTEK). Pola pengajaran dengan motto anak belajar dari apa yang dia lihat, dia dengar, dan dia rasa, dengan menggunakan model area. Hal ini mendorong rasa keingintahuan peneliti bagaimana disposisi matematis pada anak usia dini dikembangkan melalui program belajar di lembaga PAUD Permata Hati Aisyiyah Kota Tasikmalaya.

\section{METODE PENELITIAN}

Jenis penelitian yaitu penelitian kualitatif dengan metode studi kasus.
Adapun studi kasus dipilih karena bertujuan untuk menganalisis unit tertentu yaitu kelompok anak usia 3-5 tahun pada kegiatan belajar matematika dengan variabel yang diamati yaitu disposisi matematis di PAUD Permata Hati Aisyiyah Tasikmalaya (Ary, 2010: 454).

Disposisi matematis pada anak usia dini yang diamati pada penelitian ini meliputi:

a. Aspek kepercayaan diri menggunakan matematika, dengan indikator: aktif dan yakin dalam beraktifitas, berani/ tidak takut salah, menolong orang lain yang kesulitan.

b. Keingintahuan dalam melakukan matematika, dengan indikator: bertanya, antusias, menunjukkan ketertarikan, senang mencoba hal baru, tidak mudah frustasi.

c. Ketekunan/ kegigihan dalam melakukan matematika, dengan indikator: sungguh-sungguh dalam melakukan aktifitas, tidak mudah menyerah, menyelesaikan tugas yang diberikan.

d. Fleksibilitas dan daya temu dalam melakukan matematika, dengan indikator: memikirkan banyak cara, bertukar pikiran, bekerja sama, menghargai pendapat berbeda.

e. Apresiasi terhadap matematika, dengan indikator: menceritakan pemikiran matematisnya, menghargai dan menyadari penggunaan matematika dalam kehidupan sehari-hari.

Adapun metode pengumpulan data dengan cara observasi, wawancara dan analisis dokumen. Instrumen yang 
digunakan yaitu menggunakan lembar observasi dengan bentuk catatan anekdot dan rating scale. Analisis data dilakukan dengan triangulasi data dari ketiga metode pengumpulan data tersebut.

\section{HASIL DAN PEMBAHASAN}

a. Deskripsi Hasil Wawancara

1) Wawancara dengan Kepala Sekolah

Kepala sekolah menyatakan bahwa model area menjadi pilihan dalam model penataan kelas sebagai pendukung pembelajaran di PAUD Permata Hati Aisyiyah Kota Tasikmalaya.

Berikut merupakan area matematika yanga ada di kelompok A.

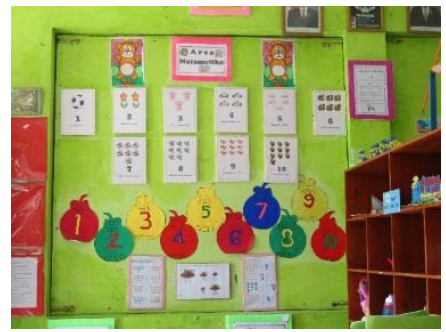

Gambar 1. Area Matematika Kelompok A

Kepala sekolah menyatakan bahwa pengenalan konsep matematika bagi anak di PAUD Permata Hati Aisyiyah, sebagian besar dilakukan dengan bantuan majalah. Majalah sebagai alat bantu anak dalam memperdalam keterampilan matematika. Selain menggunakan majalah, dalam proses pembelajaran matematika anak dibantu dengan menggunakan berbagai Alat Peraga Edukasi (APE). Misalnya saja dengan menggunakan gambar buah-buahan berwarna, dengan diberikan nomor 1-10 seperti tampak pada area matematika kelompok A pada gambar 1.

Namun demikian, kepala sekolah menyatakan bahwa keterampilan guru dalam berkomunikasi dengan anak menjadi faktor utama dalam keberhasilan pembelajaran. Misalnya stimulasi berpikir anak dengan percakapan, "ini warnanya apa saja? ... ada berapa warnanya? ada berapa banyak buahnya? ini bentuknya apa?". Guru harus aktif dalam berbincang atau berdiskusi dengan anak sebagai stimulus agar anak memberikan respon yang diharapkan, terutama pada anak di kelompok A. Percakapanpercakapan matematis yang dibangun oleh guru diharapkan mampu diterima dan menjadi scaffolding bagi anak untuk memahami konsep-konsep matematika.

2) Wawancara dengan Guru

Berdasarkan hasil wawancara dengan guru kelompok A, pembelajaran matematika di PAUD Permata Hati Aisyiyah Kota Tasikmalaya dilakukan dengan menggunakan berbagai media. Media yang digunakan diantaranya majalah kognitif dan penggunaan APE.

Guru menyatakan bahwa pada kelompok A, untuk mengenalkan konsep matematika biasanya menggunakan APE yang 
terbuat dari benda nyata dan dapat dimanfaatkan dari keseharian yang dekat dengan siswa. Misalnya, dari susu kotak kemasan dengan ukuran berbeda, kemudian bekas kotak susu disusun oleh anak dari ukuran terkecil ke terbesar. Selain mengenalkan tentang pola matematika, sebelumnya anak dikenalkan mengenai susu.

Selain itu, bisa menggunakan permainan pengelompokkan benda berdasarkan warna, anak belajar untuk mengenal pola warna, kemudian menghitung dan menyebutkan jumlah dari suatu himpunan warna. Misalnya menggunakan tomat yang warna merah dan hijau.

Meskipun menggunakan benda nyata, namun terdapat kendala dalam pembelajaran. Kendala yang sering dialami yaitu terdapat anak yang sangat aktif sekali dan anak yang pasif, sehingga guru harus pintar berkomunikasi dengan anak. Memberikan aturan yang jelas, dan memberikan percakapanpercakapan untuk memancing anak untuk merespon stimulus yang diberikan.

Selain menggunakan benda nyata, penggunaan majalah juga menjadi pilihan dalam pembelajaran matematika di kelompok A dan B, terutama di kelompok B. Adapun gambaran majalah kognitif yang digunakan dalam pembelajaran matematika terlihat pada gambar 2 berikut.

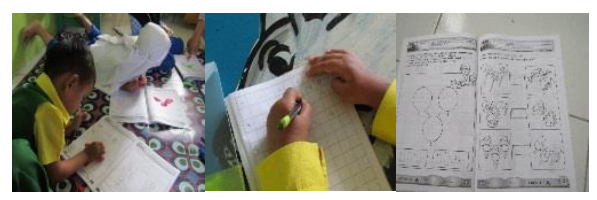

Gambar 2.

Majalah Kognitif yang

Digunakan Anak

b. Deskripsi Hasil Analisis Dokumen Berdasarkan analisis

Rencana Program Pembelajaran Harian (RPPH), Kegiatan ini pembelajaran sebagian besar menggunakan pendekatan saintifik, melalui proses mengamati, menanya, mengumpulkan informasi, dan mengkomunikasikan. Media yang diguankan sebagian besar menggunakan media majalah dalam proses belajar matematika, ataupun media yang dibuat oleh guru.

c. Deskripsi Hasil Observasi

1) Deskripsi Pengembangan Disposisi Matematis Anak dalam Kegiatan Pembelajaran

Observasi pembelajaran di kelompok A dilakukan peneliti sebanyak 9 kali, dibantu oleh pengumpul data dan pembantu peneliti. Pada kelompok A yang terdiri dari 15 anak, terdapat satu anak yang usianya dibawah 4 tahun, sedangkan 14 orang lainnya berusia antara 4-5 tahun. Pada usia ini anak cenderung berada pada periode intuitif (Schunk, 2012: 237), sudah mampu melihat dunia berdasarkan perspektif sendiri. Meskipun anak belum memiliki kemampuan konservasi volum, bilangan, panjang, berat dan luas, 
namun sudah mampu menggunakan simbol dan bahasa untuk menggambarkan imajinasinya.

Adapun beberapa program belajar matematika (kegiatan inti) dan aktivitas anak yang dilaksanakan di PAUD Permata Hati Aisyiyah beserta indikator disposisi yang muncul dalam prosesnya dijelaskan sebagai berikut.

a) Kegiatan Baris (SOP Persiapan Masuk)

Sebelum kegiatan pembelajaran ini dilaksanakan, di PAUD Permata Hati Aisyiyah anak-anak diminta untuk berkumpul di depan kelas dan berbaris. Pada saat berbaris ini, anak melalukan pola tepukan yang harus diikuti. Pola ini merupakan konsep matematis, melatih kemampuan anak untuk berpikir secara dan bernalar. Selain itu, teradpat nyanyian yang liriknya mengandung hitungan matematis (satu, dua, tiga, empat, lima, enam, tujuh, delapan, sembilan, sepuluh), selengkapnya terdapat pada video saat kegiatan berlangsung. Sebagai ilustrasi disajikan pada gambar 3 berikut.

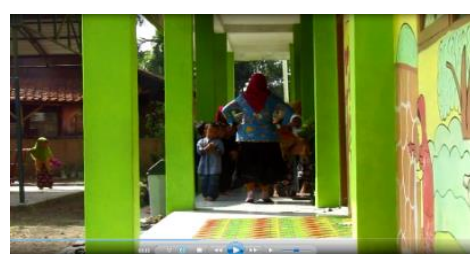

Gambar 3.

Kegiatan Berbaris

Anak terlihat percaya diri ketika melakukan perhitungan menggunakan nyanyian. Anak menunjukkan keaktifan dan keberanian untuk mengikuti pola gerakan dan nyanyian guru, termasuk ketika menyanyikan lirik bilangan anak terlihat sangat percaya diri. Hampir setiap anak, terlihat antusias dan senang menirukan nyanyian bilangan dan pola dalam kegiatan berbaris, hal ini menunjukkan anak memiliki keingintahuan yang tinggi.

Selain itu, anak tampak tekun dan menunjukkan apresiasi terhadap konsep pola tepukan yang diarahkan oleh guru. Hal ini menunjukkan disposisi matematis anak muncul ketika konsep matematika disajikan dalam bentuk gerakan atau nyanyian.

b) Penggunaan Media Maze Geometri atau Lintasan

Saat kegiatan bermain, anak diberikan APE Maze Geometri berupa lintasan seperti tampak pada gambar 4 berikut.

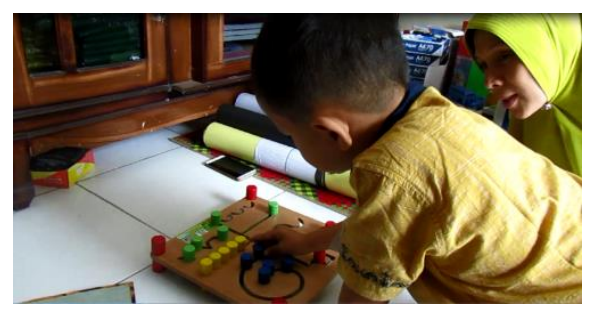

\section{Gambar 4.}

\section{Anak Bermain Maze Geometri}

Berbentuk lintasan

APE ini mengenalkan konsep geomteri berpikir visual dengan mengenal arah dan lintasan. Selain itu, pin-pin berbentuk tabung, memberikan pengalaman visualisasi bentuk geometri. Ketika 
melihat permainan tersebut, anak langsung antusias dalam memainkan pin-pin berwarna melalui lintasan dalam Maze tersebut. Anak tekun ketika diminta untuk mengelompokkan pin yang berwana kuning, biru dan hijau dalam satu jalur. Kemampuan anak dalam melakukan matematika yang dilakukan dengan kehendak sendiri tanpa bertanya ketika melakukan pengelompokkan menunjukkan anak percaya diri dalam melakukan matematika, termasuk ketika diminta untuk menyebutkan berapa jumlah pin kuning, anak menghitung satu-persatu kemudian dengan percaya diri menyebutkan jumlahnya. Indikator-Indikator disposisi tersebut muncul melalui penggunaan APE Maze Geometri.

c) Media Balok Susun

$$
\text { Media balok susun }
$$
digunakan untuk mengenalkan anak terhadap konsep geometri bentuk, bangun ruang khususnya. Anak secara alami memiliki ketertarikan terhadap balok susun. Setiap ada kesempatan untuk istirahat dari kegiatan ini, anak memainka balok susun. Mencoba mengkombinasikan beberapa bangun untuk membuat bangun yang lain, seperti tampak pada gambar 5 berikut.

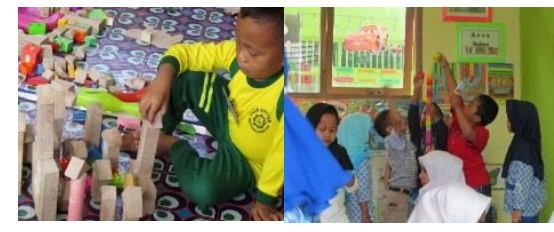

Gambar 5

Bermain Balok Susun
Melalui permainan ini, indikator disposisi yang muncul pada anak yaitu anak terlihat sangat percaya diri ketika mengkomposisikan balok menjadi bangun tertentu berdasarkan imajinasinya, misalnya membuat rumah, menara atau jembatan. Selain itu, Fleksibilitas dan daya temu anak muncul ketika mereka dihadapkan pada masalah bagaimana agar balok yang disusun kokoh dan terlihat lebih indah, hal ini mendorong mereka untuk mengapresiasi matematika dalam kehidupan sehari-hari meskipun dalam bentuk miniatur bangunan. Rasa ingin tahu dan tekun ketika mengerjakan komposisi dan dekomposisi bangun juga muncul pada diri anak ketika bermain balok susun.

d) Mengenal Pola Lingkaran atau Bola dengan Mewarnai dan Bermain

Salah satu kegiatan ini yang dilaksanakan dalam program belajar matematika kelompok A di PAUD Permata Hati Aisyiyah yaitu mewarnai, seperti tampak pada gambar 6 berikut.

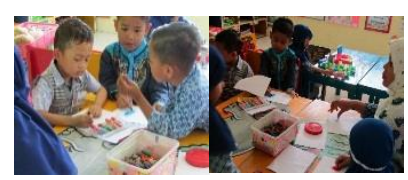

\section{Gambar 6}

Mewarnai Lingkaran

Indikator disposisi yang muncul, anak antusias dalam mewarnai area lingkaran (konsep luas), anak percaya diri ketika mewarnai bentuk lingkaran, akan 
tekun menyelesaikan tugas mewarnai area lingkaran, anak percaya diri ketika menunjukkan/ menempel hasil karyanya di kelas.

2) Deskripsi Kecenderungan Disposisi Matematis Anak Usia 3-5 Tahun di Kelompok A PAUD Permata Hati Aisyiyah

Pada kelompok A PAUD

Permata Hati Aisyiyah, terdapat 15 anak dengan usia 3-5 tahun. Anak yang berusia di bawah 4 tahun terdapat satu orang dan 14 orang berusia 4-5 tahun. Berdasarkan hasil pengamatan 9 kali di kelompok A, kecenderungan disposisi anak usia $3-4$ tahun (dalam kelompok pengamatan 3,5 tahun), anak cenderung memiliki percaya diri yang tinggi dalam menyelesaikan tugas atau aktifitas matematika yang diberikan. Selain itu, anak terlihat tekun dan memiliki rasa ingin tahu dan cukup gigih ketika melaksanakan tugas matematika. Namun, indikator fleksibilitas dan apresiasi terhadap matematika belum muncul secara optimal.

Sedangkan pada usia 4-5 tahun, indikator disposisi yang sering teramati dalam setiap aktivitas matematika yang diberikan yaitu kepercayaan diri menggunakan matematika, keingintahuan dalam melakukan matematika terutama kaitan dengan konsep geometri dengan frekuensi yang lebih besar. Sedangkan tekun dan fleksibilitas, muncul namun tidak dominan. Adapun indikator apresiasi terhadap matematika sesekali muncul, ketika program belajar menggunakan APE yang berhubungan dengan keseharian siswa, misalnya bangun, tarian, dan makanan.

\section{SIMPULAN}

Berdasarkan hasil penelitian, dapat disimpulkan bahwa program pembelajaran matematika di PAUD Permata Hati Aisyiyah pada Kelompok A, memiliki potensi mengembangkan disposisi matematis anak. Karakteristik program yang paling potensial, yaitu program belajar matematika yang melibatkan objek nyata dan APE yang beragam, termasuk penggunaan seni dalam pengenalan konsep matematika. Hal ini sejalan dengan hasil temuan penelitian yang menunjukkan implementasi permainan matematika kreatif pada siswa taman kanak-kanak yang disesuaikan dengan karakteristik, kebutuhan, serta minat anak mampu meningkatkan kemampuan matematis pada aspek number sense (Mirawati, 2015: 58). Kecenderungan disposisi matematis anak usia 3 tahun yaitu memiliki percaya diri yang tinggi dalam menyelesaikan tugas atau aktifitas matematika yang diberikan. Selain itu, anak terlihat tekun dan memiliki rasa ingin tahu dan cukup gigih ketika melaksanakan tugas matematika. Namun, indikator fleksibilitas dan apresiasi terhadap matematika belum muncul secara optimal. Sedangkan pada usia 4-5 tahun, kecenderungan disposisi matematis yang muncul yaitu kepercayaan diri menggunakan matematika, keingintahuan dalam 
melakukan matematika terutama kaitan dengan konsep geometri. Indikator ketekunan, fleksibilitas, dan apresiasi terhadap matematika muncul namun tidak dominan.

Berdasarkan hasil penelitian, disarankan bagi lembaga PAUD dan Guru untuk menggunakan APE atau media yang berkaitan dengan keseharian siswa, sehingga potensi kemunculan disposisi matematis anak lebih tinggi. Selain itu, disarankan untuk penelitian lanjutan untuk pengembangan media pembelajaran maupun program belajar matematika yang lebih berpotensi untuk mengembangkan disposisi matematis berdsarkan karakteristik pembelajaran sebagaimana hasil penelitian ini, misalnya pembelajaran STEM.

\section{UCAPAN TERIMAKASIH}

Ucapan terimakasih kepada Direktorat Riset dan Pengabdian Masyarakat Direktorat Jenderal Penguatan Riset dan Pengembangan Kementerian Riset, Teknologi, dan Pendidikan Tinggi yang telah membiayai penelitian dengan judul "Disposisi Matematis Pada Anak Usia Dini”.

\section{DAFTAR PUSTAKA}

Ary, D., Jacobs, L.C. \& Sorensen, C.K. 2010. Introduction to research in education $\left(8^{\text {th }} \mathrm{ed}\right.$.). Belmont, CA: Wadsworth.

Clements, D., Kennedy Endowed, \& Julie Sarama. 2013. Math in the early years. The progress of education reform, Vol. 14, No. 5, 1-7.
Clements, D.H. \& Julie Sarama. 2009. Learning and teaching early math: the learning trajectories approach. Madison Ave, New York: Routledge Routledge Taylor \& Francis Group.

Colgan, Lynda. 2014. Making math children will love: building positive mathitudes to improve student achievement in mathematics. Research into practice, Research Monograph \#56, August, 1-4.

Duncan, Greg J., et al. 2007. School readiness and later achievement. Developmental Psychology, Vol.43., No. 6, 14281446.

Graven, Melony. 2016. Strengthening maths learning dispositions through math 'clubs'. South african journal of childhood education, 1-7, ISSN 22237682.

Kilpatrick, J.J., Swafford \& Bradford F. 2001. Adding it up helping childern learn mathematics. Washington DC: National Academy Press.

Mahmudi, A. 2010. Tinjauan asosiasi antara kemampuan pemecahan masalah matematis dan disposisi matematis. Yogyakarta: FMIPA Universitas Negeri Yogyakarta.

Mirawati, M. 2015. PENERAPAN PERMAINAN MATEMATIKA KREATIF DALAM MENINGKATKAN NUMBER SENSE ANAK TAMAN KANAK-

KANAK. Edusentris, 2(1). 
NAEYC. 2002. Early childhood mathematics: promoting good beginnings. National Association for the Education of Young Children.

National Mathematics Advisory Panel (NMP). 2008. Foundation for succes: the final report of the national mathematics advisory panel. U.S. Department of Education.

NCTM. 1989. Curriculum and evaluation standards for school mathematics.

NCTM, Inc: Resto, Virginia.

Nurkamilah, M., Nugraha, M. F., \& Sunendar, A. 2018. Mengembangkan Literasi Matematika Siswa Sekolah Dasar melalui Pembelajaran Matematika Realistik

Indonesia. Theorems, 2(2).

Nurkamilah, Milah. 2016. Keefektifan pembelajaran lingkaran menggunakan guided discovery learning dengan setting kolaboratif ditinjau dari prestasi belajar matematika, kemampuan komunikasi matematis, dan selfefficacy matematis siswa kelas viii smp. Tesis : Universitas Negeri Yogyakarta. Tidak diterbitkan.

Rahayu, R. \& Kartono. 2014. The effect of mathematical disposistion toward problem solving ability based on IDEAL problem solver. International journal of science and research (IJSR), ISSN(Online:2319-7065, Vol.3, 1315 1318.

Sarama, J. \& Douglas H. Clements.
2009. Early childhood mathematics education research, learning trajectories for young children. Madison Ave, New York: Routledge Routledge Taylor \& Francis Group.

Schunk, Dale H. 2012. Learning theories: an educational perspective. Boston: Pearson.

Watts, T.W., et al. 2014 . The groove of growth: how early gains in math ability influence adolescent achievement. SREE Spring Conference, A1-A-7). 